TALES FROM CHIRGWIN HOSPITAL 


\section{Themes in Nursing}

Can nurses care more? It is increasingly clear that there are several essential elements of nursing which are quite distinct from the specific clinical aspects of each specialty. These central elements are required throughout nursing and demand additional skills and understanding, and are of vital importance in the successful delivery of effective patient care. Among the topics to be covered in this series are: care and management; research for practising nurses; care of the patient in pain; health education; and care of people from different ethnic backgrounds.

As nursing develops it becomes more important that collaboration between the various caring professions is reinforced. Each topic in this series will be dealt with in a practical way by authors with understanding and experience of the clinical environment. To achieve this, authors have been chosen to represent a wide range of the relevant caring professions.

This series is designed to provide nurses and their colleagues with the resource of knowledge and the stimulus for discussion required by effective professionals. The books in the series can be used quite independently, but together will give an overall coverage of the key issues in clinical nursing.

These are important topics throughout nursing, both in hospital and in the community, and all practising nurses need a full understanding of them. 


\title{
Tales from Chirgwin Hospital
}

\section{A Question of Management}

\author{
Courtenay C. Wade
}

with illustrations by

Audrey Pratt

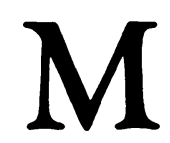

MACMILLAN PRESS

LONDON 
Text $\odot$ Courtenay C. Wade 1983

Illustrations $\odot$ The Macmillan Press Ltd 1983

Softcover reprint of the hardcover 1st edition 1983 978-0-333-34745-4

All rights reserved. No part of this publication may be reproduced or transmitted, in any form or by any means, without permission

First published 1983 by

THE MACMILLAN PRESS LTD

London and Basingstoke

Companies and representatives throughout the world

ISBN 978-0-333-34746-1 ISBN 978-1-349-17233-7 (eBook)

DOI 10.1007/978-1-349-17233-7

Typeset by

Multiplex techniques limited, Orpington, Kent

The reader should note that all references in this book to one gender should also be read as applying to the other gender unless specifically indicated otherwise 
To my reader, critic, encourager, friend and dictionary: my wife. 


\section{Contents}

Foreword ix

Acknowledgements $\quad$ xi

Introduction 1

Tale 1 Administration 5

$\begin{array}{lll}\text { Tale } 2 \text { The Acute Surgical Ward } & 13\end{array}$

Tale 3 The Geriatric Assessment Ward 28

Tale 4 Cross-infection 49

$\begin{array}{lll}\text { Tale } 5 & \text { Communication } & 70\end{array}$

Tale 6 The Outpatient Department 83

Tale 7 The Accident and Emergency Department 94

Tale 8 The Cracked Cup 116

Tale 9 The Old Building 136 


\section{Foreword}

by

Sheila M. Collins, OBE, BA, SRN, RSCN, RNT, FRCN

These tales offer a fresh approach to the issues which affect the care of our patients, and they will appeal to all those who are concerned about the quality of the service provided by those in the caring professions. The focus in each tale is on the patient and his needs - but the events are described from differing perspectives - from the views of the patient and his relatives and friends, from the nurse and the doctor, from the social worker and the paramedical staff, and from the health service administrator.

This thread of caring about people and about the quality of the health service runs through each tale - light-hearted but serious, compassionate but realistic - compelling us to ask ourselves questions about our own work and the effectiveness of the health care team. Patients are people who need the understanding support of nurses and doctors, and of many others who contribute to their care at home and in hospital. Teamwork, in which the nurse plays a central co-ordinating role, is essential for a successful outcome. Yet how often is the person (who happens at that time to be called a patient) considered to be the object of professional care rather than an active participant in the caring team?

These tales exemplify the everyday dilemmas in hospital, for both patient and staff, e.g. the waiting time in the clinic, the lengthening waiting list for admission, the precipitate discharging of the patients, the lack of maintenance (and hence the discomfort) in newly designed hospitals, and many others. Both student and pupil nurses and trained nurses will find common ground and additional evidence from their own experiences to discuss with each other and with their medical and paramedical colleagues at ward team meetings. As professional nurses in clinical practice, in teaching or in managing the nursing service, we are responsible for the standards of care we offer to our patients. Only by frank discussion between different disciplines can the realities of the situation be fully explored. 
Managing resources is about helping people to understand their common aims, and to appreciate how each individual contributes to the whole service. This book challenges its readers - potential patients and others - to discuss the real issues which are fundamental to good practice and to the standards of care we wish to offer and would wish to receive in the circumstances so aptly described in each tale.

Bromley, Kent, 1983 


\section{Acknowledgements}

My thanks are due to many people. Thank you, those who have helped me during the writing of this book; those who gave their views long years ago in a ward at night or over coffee in the casualty department; those who are still learners; those who are senior; those who have left nursing; those, alas, now dead.

Let me acknowledge Ann, Anne, Audrey, Barbara (i), Barbara (ii), Brenda, Catherine, Charles, Derek, George, Hilda, Hugh, Jeannie, JEK, Jenny, Joan (i), Joan (ii), John (i), John (ii), Joyce (i), Joyce (ii), Judy, Lilian, Mandy, Margaret (i), Margaret (ii), Mary (i), Mary (ii), Mary Ann, Nicky, Nigel, Paul, Peter, Roma, Sandy, Sheila, Siobhan, Susie and Tony. My special thanks are due to Vera Darling and Jill Rogers, to Richard Powell, and to Elizabeth Horne of The Macmillan Press, who have had to put up with me during the preparation of this book. They have shown patience and have been brave. I must also thank Marion Worsell who, with speed and skill, typed the manuscript.

If I have forgotten valuable assistance, let me seek forgiveness now: from the remembrancers and the oppugners.

Croydon, Surrey, 1983

C.C.W. 